\title{
The highest court affirms an empty right
}

Published at www.cmaj.ca on June 20, 2005.

Tn a narrow and contentious 4:3 decision in the appeal case of Chaoulli v. Quebec (Atttorney General), the Supreme Court of Canada has struck down Quebec laws prohibiting the sale of private health insurance on the basis that they violate Quebec's Charter of Human Rights and Freedoms. Of the 7 judges, 3 of the 4 in the majority opinion also found these laws to be in violation of section 7 of the Canadian Charter of Rights and Freedoms. This raises the prospect that similar laws in other provinces may be struck down. However, in a blistering dissent, the minority found that the insurance restrictions violated neither the Quebec nor the Canadian charter.

In reaching their decision the majority of the Supreme Court judges came to 3 conclusions that we will review here. First, that waiting lists in Canada are too long; second, that the ability to purchase private insurance will mean that Canadians will not have to wait for treatment; and, third, that there is no evidence that the existence of a private insurance system will undermine the quality of publicly funded medicare.

The court finds that the risk to life presented by inordinate wait times for treatment contravenes the Charter's guarantee of life, liberty and security of the person. Although one can track down such cases, the evidence that the court relies on in concluding that Canadians are dying prematurely because of long waiting lists is entirely anecdotal. We can, however, see their reaa soning in concluding that the psychological effects of long waits constitute a breach of the Charter's guarantee of security of the person. There is absolutely no merit to being on a 2 -year waiting list for hip replacement or waiting 16 weeks for radiation after breast-conserving surgery. But, as the minority judgment succinctly points out, how long is too long to wait from a constitutional perspective? We know well that inappropriate waits for cancer therapy vary enormously from condition to condition and that the determination of acceptable wait times is an extremely difficult process driven largely by consensus, not by scientific views of evidence. By way of remedy for this infringement, the court provides no direction in the adjudication of wait times, leaving a sense that any wait is too long, thus opening the door to a variety of challenges related to access and, potentially, technology as well. All systems impose some form of rationing, whether by price or through wait lists. Jurisdictions with two-tier health care systems such as the United Kingdom and New Zealand struggle in their public systems with wait lists that historically have been longer than those in Canada. ${ }^{1}$ This fact is as worthy of consideration as much of the other evidence submitted on waits.

Rather than suggesting a remedy tied to wait times, the majority judgment then goes on boldly to conclude that if Canadians could purchase private insurance they would not have to suffer long waits for treatment. But most Canadians would not benefit from the introduction of private insurance. Across all OECD countries, the people who buy private insurance are generally the wealthiest, who are the healthiest in society. Medicare in Canada was created precisely to eliminate distinctions between rich and poor in access to health care. As the earlier trial judge rightly noted, the legislative provisions protecting medicare were not arbitrary, but were motivated by considerations of equality and human dignity. The other as- sumption the majority make is that private insurance will cover treatments for which there are presently long wait times, such as cardiac surgery. But in two-tier systems private insurance typically does not cover the tough stuff like cancer care and cardiac treatments. The private tier covers the relatively easy, high-volume procedures, and typically covers more intensive interventions only when required to do so by law or when they are heavily subsidized by government.

To repeat, it appears that countries with two-tier systems appear to have longer, not shorter, wait times. Why is this so? Common sense would lead us to expect that people who pay through private insurance for services that are covered by the public system reduce the burden on the public system. But it is also a market imperative that public systems must perform poorly for parallel private insurance markets to have value. The majority judgment assumes that new physicians and nurses will materialize out of thin air to staff the private sector when, of course, they must come from an already taxed public system; when they are treating private patients, they will not be attending to the queues in the public system. This is not a problem the market can respond to overnight; it takes a long time and lots of public money to train medical professionals.

The majority of the court says there is no evidence to support the concern raised about depleted human resources except the assertions of various social scientists called as witnesses. In doing so they chose to ignore the mass of scholarly input compiled in the Senate hearings and the reports by Romanow and Kirby. But, in actual fact, this problem of limited resources is supported by evidence from other countries 
and within Canada. For example, a 1998 study showed that regions in the UK with high levels of private insurance coverage were likely to have relatively large waiting lists. ${ }^{2}$ More evidence of this problem comes from a study done in Manitoba during a period in which cataract surgery was offered on a private basis. It was found that, by the time this practice was disallowed in 1996, waiting times were over twice as long for publicly financed services provided by surgeons who practised in both sectors (23 weeks) as those provided by surgeons who practised only in the public sector (10 weeks). ${ }^{3}$ Moreover, many other countries take measures to suppress the flourishing of the private sector. ${ }^{4}$ Surely the Supreme Court does not consider the governments of all these countries to be in pursuit of irrational and arbitrary policies?

The majority judgment of the court relies heavily on a characterization of Canada as being unique in its position as a developed country that prohibits private funding for hospital and physician services. But a sharp distinction cannot be drawn between Canada and the rest of the developed world for the simple reason that the public-private distinction is blurred in many countries. For example, in Australia enormous public subsidies flow to the private sector, and legislation prevents private insurers from avoiding risk by refusing to cover patients with preexisting conditions or comprehensive needs. But this form of financing is far more regressive, far less fair, than that achieved through public funding. It's true that Canada is one of only a handful of countries with explicit bans on private health insurance for hospital and physician services. Other countries arrive at the same end by different means. Indeed, countries that care about a fair distribution of health care spend a lot of time trying to compensate for the ill effects that flow from allowing a private insurance sector to operate side by side with the public sector. The
UK tries to regulate the amount of time specialists work in the public sector. New Zealand would like to consider similar measures but faces resistance from the medical profession, which wants to retain the ability to bill privately. Sweden, Luxembourg, Greece and Italy have responded to the problem of capacity and the concern that doctors will divert their time and energy from the public sector to the private sector by prohibiting doctors from practising in both the sectors at once. ${ }^{4}$

What can we expect in the wake of Chaoulli? In our view, there are so many ambiguities within the decision that it is unlikely to deeply compromise medicare. In particular, provincial governments can protect the quality of the public sector in other ways besides a formal ban on the sale of private insurance. Provinces in Canada regulate independent health facilities and hospital licences very carefully, and these efforts constrain private coverage further and can be reviewed and strengthened if required. Some provinces in Canada, similarly to a number of OECD countries, don't prohibit private insurance but do prohibit physicians from working both in the public sector and in the private sector. ${ }^{5}$ Physicians must be either in the public system or out of it. Without being able to piggyback or to beggar the public system, there is only limited scope for private markets, as experience in the 3 provinces that have no ban on private insurance attests. Justice Deschamps spoke of these measures as legitimate means for governments to use to protect the public system (as opposed to an explicit ban on private insurance). Presumably, in any future challenge, she then would join with Justices Binnie, LeBel and Fish (who wrote the dissent in Chaoulli) and not find these laws to be in contravention of section 7 of the Charter. Thus the real effect of this decision is to protect an empty right: without a flourishing private sector the right to purchase private insurance is meaningless.
Ironically, there are important initiatives presently under way in provinces to better manage and attend to waiting times. Perhaps these efforts to measure, report and clarify responsibility for wait-list reductions will be redoubled and spurred on by the Chaoulli decision. But the federal government, despite its shaky current posture must, finally, step up to the regulatory plate. It cannot avoid responsibility for this strange decision, or plead fear of further constitutional challenges. This decision arises in large measure from a failure of political leadership on public health care. If the provinces proceed to allow, in contravention of the Canada Health Act, private financing for medically necessary services, then Prime Minister Martin must impose the financial penalties so carefully avoided by Mr. Chrétien during his tenure.

Colleen M. Flood
Associate Professor
Canada Research Chair in Health
Law and Policy
Faculty of Law
University of Toronto
Terrence Sullivan
President
Cancer Care Ontario
Associate Professor
Health Policy Management
and Evaluation
University of Toronto
Toronto, Ont.

\section{References}

1. Tuohy C, Flood C, Stabile M. How does private finance affect public health care systems: marshalling the evidence from OECD nations. 7 Health Polit Policy Law 2004;29(3): 359-96.

2. Timothy T, Hall J, Preston I. Private and public health insurance in the UK. Eur Econ Rev 1998;42:491-7.

3. DeCoster C, Carrière KC, Peterson S, Walld R, MacWilliam L. Waiting times for surgery in Manitoba. Winnipeg: Manitoba Centre for Health Policy and Evaluation; 1998. Available: www.umanitoba.ca/centres /mchp/reports/pdfs/surgwait.pdf (accessed 2005 Jun 17).

4. Colombo F, Tapay N. Private health insurance in OECD countries: the benefits and costs for individuals and health systems. Working paper No. 15, p. 24, fn 38. Available: www.oecd.org /dataoecd/34/56/33698043.pdf (accessed 2005 Jun 17).

5. Flood CM, Archibald T. The illegality of private health care in Canada. CMA7 2001;164(6):825-30. 